\title{
D-penicillamine-induced Status Dystonicus in A Patient with Wilson's Disease: A Diagnostic \& Therapeutic Challenge
}

\author{
A. Satyasrinivas*, Y.S. Kanni, N.Rajesh, M.SaiSravanthi, Vijay kumar
}

Department of General Medicine, Kamineni Institute Of Medical Sciences, Narketpally 508254

Andhra Pradesh, India.

\section{DOI Name}

http://dx.doi.org/10.3126/jaim.v3i2.14066

\section{Keywords}

Dystonia, Gabapentin Kayser-Fleischer ring,

Trientein hydrochloride, Wilson's disease.

\section{Citation}

A. Satyasrinivas, Y.S. Kanni, N.Rajesh, M.SaiSravanthi, Vijay kumar. D-penicillamineinduced Status Dystonicus in A Patient with Wilson's Disease: A Diagnostic \& Therapeutic Challenge. Journal of Advances in Internal Medicine 2014;03(01):62-64.

\begin{abstract}
Wilson's disease is an autosomal-recessive disorder of copper metabolism resulting from the absence or dysfunction of a copper-transporting protein. The disease is mainly seen in children, adolescents and young adults, and is characterized by hepatobiliary, neurologic, psychiatric and ophthalmologic (Kayser-Fleischer rings) manifestations. . Mechanism of status dystonicus in WD is not clear We present here a case study of Wil. son's disease in 14 year old child with dystonia not responed with routine therapy.
\end{abstract}

\section{INTRODUCTION}

Wilson's disease (WD), also known as hepatolenticular degeneration was first described in 1912 by Kinnear Wilson as progressive lenticular degeneration. WD is an inherited, fatal neurological disorder accompanied by chronic liver disease leading to cirrhosis ${ }^{1}$, and accumulation of copper in the liver and brain because of defective biliary excretion ${ }^{2,3}$. Wilson's disease is due to mutations of the ATP7B gene on chromosome $13^{4,5}$.

\section{Case Report}

A 14 year old male presented with complaints of difficulty in speaking from last 3-months, dystonia from last 4 days, abnormal posture of lower limbs \& tongue from last 3months. Past history: The patients past history as narrated by his mother is as follows: He was alright till approximately last 3 months when he had an episode of fever and received medication by a private practitioner. The fever subsided after medication, but patient had developed loose stools, difficulty in speaking and pronouncing linguals. With these compliants he was admitted in the hospital. On Radio imaging and ophthalmic examination he was diagnosed as a case of Wilson's disease and was started with tablet calcium Pantothenate and tablets D-Penicillamine and was discharged. After a few days patient was again admitted in the hospital with a chief complaint of abnormal behaviour and increased dystonia which progressed to involve whole left lower limb, right foot, tongue and right upper limb. At that time he was advised to withhold DISTAMINE tablet. He was not relieved of dystonic symptoms though the behavioural symptoms decreased. On Examination: Patient was conscious, No clubbing or cyanosis .No icterus or pallor. There was no abnormality in

\footnotetext{
* Corresponding author

Dr. Satyasrivas Appala

Department of internal medicine

Kamineni Institute of Medial science Narketpally,Andhra Pradesh, India

Email:dr.satyasrinivas@gmail.com.
} 
cardiovascular, respiratory or gastrointestinal system. On examination his B.P was 130/80 mm Hg, Pulse rate was 90/ min. Investigations: Haematological investigation revealed, Haemoglobin \% - 18\%, Albumin: $3.0 \mathrm{~g} / \mathrm{dl}$, Serum Creatinine: $1.2 \mathrm{mg} / \mathrm{dl}$,UREA (B): 29 mg/dl ,Alanine Transaminase : $104 \mathrm{IU}$ , Aspartate Aminotranferase: 65IU ,Alkaline phosphatase : 142

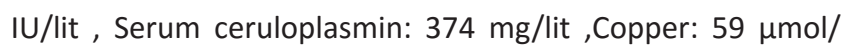
dl Slit Lamp Examination- KAYSER FLEISHER RING is present, After confirming diagnosis patient was started on Trientein hydrochloride $300 \mathrm{mg}$ three times a day (TDS), Benzhexol $2 \mathrm{mg}$ four times in a day (QDS)gabapentin $80 \mathrm{mg}(\mathrm{ODS})$. Follow up is being taken regularly for next six months. Patient is gradually improving and still continuing treatment.D-penicillamineinduced aggravation of dystonia is known in patients with Wilson disease. ${ }^{6,7,8}$ Similar aggravation of dystonia is also known with Trientine and zinc ${ }^{9}$ monotherapies; the condition is however more severe with D-penicillamine. D-penicillamine does not produce dystonia when used in other disorders, like rheumatoid arthritis, copper sulfate or arsenic poisoning. Underlying mechanism of D-penicillamine-induced status dystonicus in WD is not clear. Increased copper turnover secondary to copper chelation, resulting in injury to basal ganglia, thalamus and brainstem is a likely possibility. The signal changes in thalamus and brainstem observed on MRI during D-penicillamine-induced increase in dystonia may reverse back to normal on discontinuation of D-penicillamine. ${ }^{8}$

D-penicillamine-induced status dystonicus responds poorly to anti-dystonia drugs. Our patient responded well to gabapentin after failing to respond to other anti-dystonia drugs. Gabapentin can improve limb dystonia, hemifacial spasms, hemichorea/ hemibalismus and torticollis. ${ }^{10,11,12}$ Interestingly, gabapentin evoked good response in patients with familial paroxysmal nonkinesogenic dyskinesia. ${ }^{12}$ In our patient, gabapentin improved paroxysmal dystonic spells more than the sustained dystonia. Mechanism of action of gabapentin in paroxysmal dyskinesia and paroxysmal dystonic spells is not known. Gabapentin inhibits K1-evoked Ca21 increases in neocortical synaptosomes via inhibition of voltage-dependent calcium channels (VD-CCs) and reduces K1-evoked glutamate release from neocortical and hippocampal slices. ${ }^{13,14}$ It also inhibits excitatory neurotransmitter release in the dorsal horn of cord dorsal. These actions of gabapentin are hypothesized due to its selective agonist activity at neuronal GABA ${ }_{B}$ receptors, which are coupled to VD-CCs. ${ }^{15}$ Possibly, these mechanisms make gabapentin effective against other paroxysmal disorders like migraine, epilepsy, trigeminal neuralgia, neuromyotonia. These mechanisms can also be hypothesized for the response evoked in our patients of paroxysmal dystonic spells. Patients with WD may have associated clinically overt or subclinical hepatopathy. Since gabapentin has renal route of clearance, its use is safe in these patients.

Conclusion: Status dystonicus with paroxysmal dystonic spells is a rare but serious complication of D-penicillamine therapy in patients with WD. Underlying mechanism of this condition is not known. Gabapentin can be used to control D-penicillamineinduced paroxysmal dystonic spells in patients with WD.

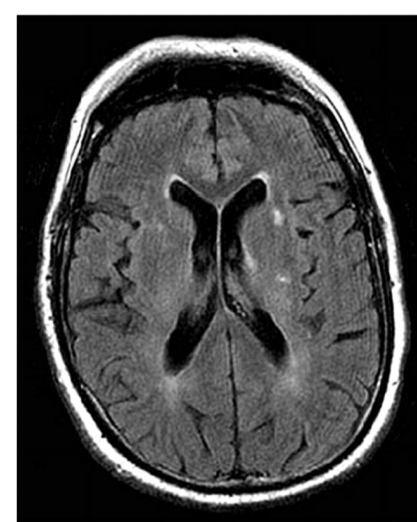

MRI AFTER STOPPING

D- PENICILLAMINE

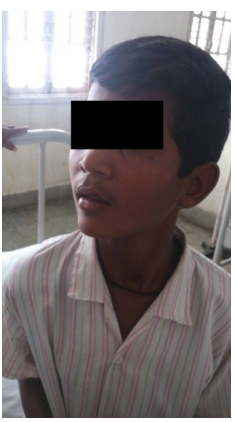

Dystonia of neck

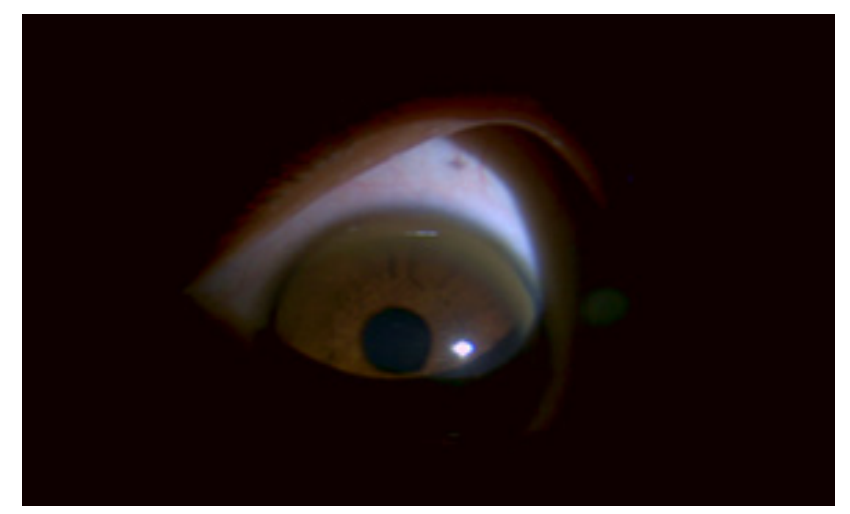

Kayser-Fleischer ring

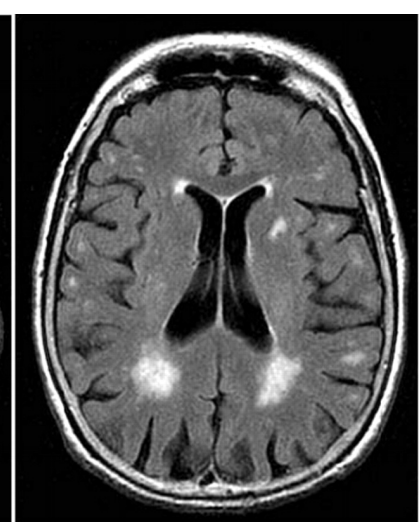

MRI WITH

D-PENICILLAMINE THERAPY
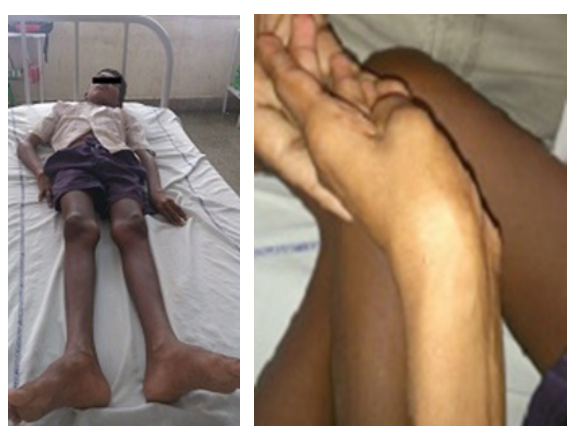

Dystonia of upper limb 


\section{REFERENCES}

1. WilsonSAK.Progressive lenticular degeneration:a familial nervous disease associated with cirrhosis of liver.Brain1912;34:295507

2. ScheinbergIH,Sternberg I.Wilson's disease.In:Smith Jr LH,editor.Major problems in internal medicine,vol23. Philadelphia,PA:WB Saunders;1984 p.25-35.

3. Gitlin JD.Wilson disease. Gastroenterology 2003;125:1868-1877.

4. Tao TY,Gitlin JD.Hepatic copper metabolism.Insights from genetic disease.Hepatology 2003;37:1241-1247.

5. Lutsenko S,Petris MJ.Function and regulation of the mammalian copper transporting ATPases:insights from biochemical and cell biological approaches.J Membr Biol 2003;191:1-12

6. Stevel M,Sternic N,Pejovic S,Kostic VS.Penicillamine -induced lethal status dystonicus in a patient with Wilson's disease.Mov Disord 2001;16:568-9.

7. Glass JD, Reich SG, Deliong MR.Neurological disease after beginning penicillamine therapy.Arch Neurol 1990;47:595-6.

8. Huang CC, Chu NS.Acute dystonia with thalamic and brainstem lesions after initial penicillamine treatment in Wilson's disease.Eur Neurol 1998;39:32-7.
9. Tieve HA,MunhozRP,Souza MM,Antoniuk SA,Santos ML,Texiera MJ,et al .Status dystonicus:study of five cases.Arq Neuropsiquiatr 2005;63:26-9.

10. L inazosoro Cristobal G.Efficacy and tolerance of gabapentin in dystonia and hemifacial spasm:A pilot study.Rev Neurol 2001;33:408-10.

11. Kothare SV,Pollack P, Kulberg AG, Ravin PD.Gabapentin treatment in a child with delayed onset hemichorea/ hemiballismus.Pediatr Neurol 2000;22:68-71.

12. Chudnow RS, Mimbela RA, Owen DB, Roach ES.Gabapentin for familial paroxysmal dystonic choreoathetosis. Neurology 1997;49:1441-2.

13. Fink K, Meder W, Dooley DJ, Go thert M.Inhibition of neuronal Ca21 influx by gabapentin and subsequent reduction of neurotransmitter release from rat neocortical slices.Br J Pharmacol 2008;130:900-6.

14. Dooley DJ,Mieske CA,Borosky SA.Inhibition of K1 evoked glutamate release from rat neocortical hippocampal slices by gabapentin.Neurosci Lett 2000;280:107-10.

15. Bertrand S, Ng GY, Pruisai MG,Wolfe SE, Severidt MW, Nouel $\mathrm{D}$,et al .Yhe anticonvulsant antihyperalgesic agent gabapentin is an agonist at brain gamma-aminobutyric acid type $B$ receptors negatively coupled to voltagedependent calcium channels. J Pharmacol Exp Ther 2001;298:15-24. 